\title{
Development of agrotourism business model as an effort to increase the potency of tourism village(case study: Punten Village, Batu City)
}

\author{
I Ketut Gunarta ${ }^{1,{ }^{*}}$ and Fuad Dwi Hanggara ${ }^{2}$ \\ ${ }^{1}$ Sepuluh Nopember Institute of Technology, Department of Industrial Engineering, 60111 Surabaya, \\ Indonesia
}

\begin{abstract}
Tourism development is generally directed as a key sector to promote economic growth, increased local revenues, empowering the community's economy, expanding employment and business opportunities, and enhancing product introduction and marketing in order to improve the welfare of the community. The development of tourist areas must be a fully planned developments that optimal benefits can be obtained for the community. One approach that can be used in creating a business model in tourism development is using Triple Layered Business Model Canvas (TLBMC) extends the original business model canvas by adding two layers: an environment layer based on a life cycle perspective and a social layer based on a stakeholder perspective. This model canvas supports development along with more comprehensive and integrated communication, a business model that also supports creative innovation toward a more sustainable business model. Tourism sector in Punten village become object of observation in this research. This study aims to create new business model by looking at economic, environmental and social condition by using Triple Layered Business Model Canvas (TLBMC) approach. This business model is also supported by SWOT analysis in evaluating strengths, weaknesses, opportunities and threats in a project or a speculation of business and tools that enable strategies to evaluate objective strategies objectively, based on previously identified internal and external key success factors. The research objectives are expected in the business development of the tourism sector in addition to the creation of new business models that will form a clear business system and provide expected results, can also formulate business strategies on the tourism sector based on the analysis that has been done.
\end{abstract}

\section{Background of Study}

The trend in the 21 st century, shows that growth in the service industry will greatly increase. One sector of the service industry that contributes enorrmously to the global economy over the last ten years is the tourism sector (Law et al, 2011). Indonesia as one of the countries in Southeast Asia has a tourism potential that is not inferior when compared

Corresponding author: samfu.31@gmail.com 
with other countries in Southeast Asia. Indonesia's tourism conditions in 2016 in macrogreatly contribute to the national Gross Domestic Product of $7.01 \%$ with the amount of foreign exchange generated amounted to USD 23.17 billion (The Tourism Ministry of The Republic of Indonesia, 2016). From the data, it is clear that tourism in Indonesia has very good potential to be developed. And one of the mis agrotourism that is developing as one of the alternative tourist destinations.

Agrotourism is a series of tourism activities that utilize the potential of agriculture as a tourist attraction, both the potential of natural landscape of agricultural areas and the peculiarities and diversity of production activities, and agricultural technology and culture of agricultural communities. According to Nurisjah (2001) in Budiarti (2013), agrotourism or agricultural tourism is defined as a series of travel activities that take advantage of location or agricultural sector from the beginning of production to agricultural product share obtained in various systems and scales with the aim of broadening knowledge, understanding, experience and recreation in agriculture. Development of agrotourism activities directly and indirectly will increase the positive perception of farmers and the community about the importance of conservation of agricultural land resources. In addition, according to Subowo (2002) in Budiarti (2013), agrotourism can conserve resources, preserve local wisdom and technology, and increase the income of farmers or communities around agrotourism. The development of agrotourism will create jobs and increase income and improve the welfare of farmers. Some of the positive impacts of agrotourism development include increasing the selling value of agricultural commodities produced and development of other sources of income that can be enjoyed by local people such as homestay rentals and other recreational facilities such as canteens, souvenir sales, and others. In addition, agro tourism is one of the effective mode in the promotion of agricultural products and culture of the archipelago.

The development of tourist village based on agrotourism is a very important thing especially for areas that have agrotourism potential, such as Batu City of East Java. As the Vision of the Batu City: "Batu City Center of Organic Agriculture Based on International Tourism". It can be seen from the number of visitors both domestic and foreign tourists who enjoy some tourist attractions located in Batu City. In the implementation of agrotourism sector development in Bumiaji District especially Punten Village has not been able to run optimally.

The problems of developing agrotourism sector in Punten Village are: 1) Lack of understanding and citizen participation on agrotourism potential; 2) The potential of tourist attractions has not been properly managed; 3) The role of agrotourism in local economic development has not been maximized; 4) Ineffectiveness of local community-based tourism institutions; 5) Lack of capacity and accessibility of infrastructure in supporting agrotourism.

From the above problems demanded agrotourism sector in Punten Village as one of the tourism villages initiated by the city government up to the village administration to be able to read the existing opportunities and able to read market conditions and can provide new innovations in business development so that the agrotourism sector can be still known as a tourist attraction that provides tourism morale for consumers as well as other stakeholders. And the absence of written regional and business development strategies from agrotourism make the agrotourism sector for now is still not known by many people. Therefore, the agrotourism sector in Punten Village must develop a new, systematic and sustainable business innovation. 


\section{Literature Review}

\subsection{SWOT Analysis}

According to Blocher et al., (2007) SWOT analysis is a systematic procedure to identify the factors that determine the success of the company's internal strengths and weaknesses, as well as opportunities and external threats. Meanwhile, according to Wantiet.al., (2014) SWOT analysisis an important strategic planning tool to help planning to compare internal strengths and weaknesses with external opportunities and threats. The SWOT analysisis based on the appropriateness between the company's internal resources and its external situation. Good conformity will maximize the company's strengths and opportunities and minimize weaknesses and threats. Strengths and weaknesses are management factors wholly in management control, where strength is the factors that have been successfully controlled which have a positive impact on the organization. While the weakness is a factor that is not successfully managed which provide a negative impact for the company. Opportunities are factors that are beyond management control, but their appearance will provide a chance for success for the company. If the company has enough power to adapt. Threats (threats) are factorsthat are outside management, but if it appears will threaten the life of the company.Threats are a major obstacle for the company in achieving its current position or desired position. Once weaknesses, strengths, and opportunities and threats can be identified, it will be processed by strategy formulation using SWOT analysis and using tables of EFAS (External Factor Analysis Summary) and IFAS (Internal Factor Analysis Summary).

\subsection{Analytical Hierarchy Process (AHP)}

Analitycal Hierarchy Process (AHP) is a method to solve an unstructured complex situation into several components in a hierarchical order, giving subjective values of the relative importance of each variable, and specifying which variable has the highest priority to influence the outcome of the situation.

The decision making process is basically choosing the best alternative. Such as structuring issues, determining alternatives, determining possible values for aleatory variables, value determers, time preference requirements, and risk specifications. No matter how widening the alternatives can be established or detailed the probable value, the limitations that remain pervasive are the basis of comparison in the form of a single criterion.

Main equipment of Analitycal Hierarchy Process (AHP) has a functional hierarchy with the main input of human perception. With the hierarchy, a complex and unstructured problem is solved into its clusters and organized into a hierarchical form.This tool can make it easier to rank alternative strategies compared to ANPs that require a network that connects between.

\subsection{Triple Layered Business Model Canvas (TLBMC)}

Triple Layered Business Model Canvas (TLBMC) is a tool to support creative exploration of sustainable business models and sustainability-oriented innovations more broadly. TLBMC complements and extends Osterwalder and Pigneur (2012). The concept of a canvas economic-oriented Triple Layered Business Model Canvas business model with a 
new layer of canvas explores the creation of environmental and social values. The concept of a economic-oriented business model canvas with a new layer of canvas explores the creation of environmental and social values. This additional layer parallels the original business model canvas by highlighting the inter connects that support separate environmental and social impacts, and extend them by drawing connections across three layers to support integrated triple perspective of bottom line impact organizations (Glaser, 2006; Hubbard, 2009; Sherman, 2012 ).In other words, TLBMC provides 'horizontal' coherence within each layer of the canvas to explore individual economic, environmental and social values and 'vertical' coherence that integrate value creation across three layer canvases; which supports the development of a deeper understanding of an organization's value creation (Lozano, 2008). Therefore, TLBMC is proposing to creatively explore product innovation, process, and innovation based on sustainability in support of organizations better addressing sustainability challenges. As the original business model canvas was developed extensively by the original authors (Osterwalder and Pigneur, 2010), the next section focuses only on the proposed new environmental and social canvas layer as part of the TLBMC.

\section{Model Development for Quality Improvement}

The development of model for quality improvement in this research will use principle in SWOT Analysis by using AHP tools in weighting alternative solution which will be inputted into TLBMC business model. In the first phase it aims to identify strengths, weaknesses, opportunities, and threats to the existing (internal and external) business conditions. Next there is a calculation on each column on the SWOT that will bring up the position in the SWOT quadrant. Next, determine the new strategy by using TOWS matrix. Furthermore, on the SWOT after the emergence of a new strategy will be weighted or ranking on strategies that have been formulated on the TOWS matrix by using AHP which aims to determine the priority of each strategy that has been formulated. 


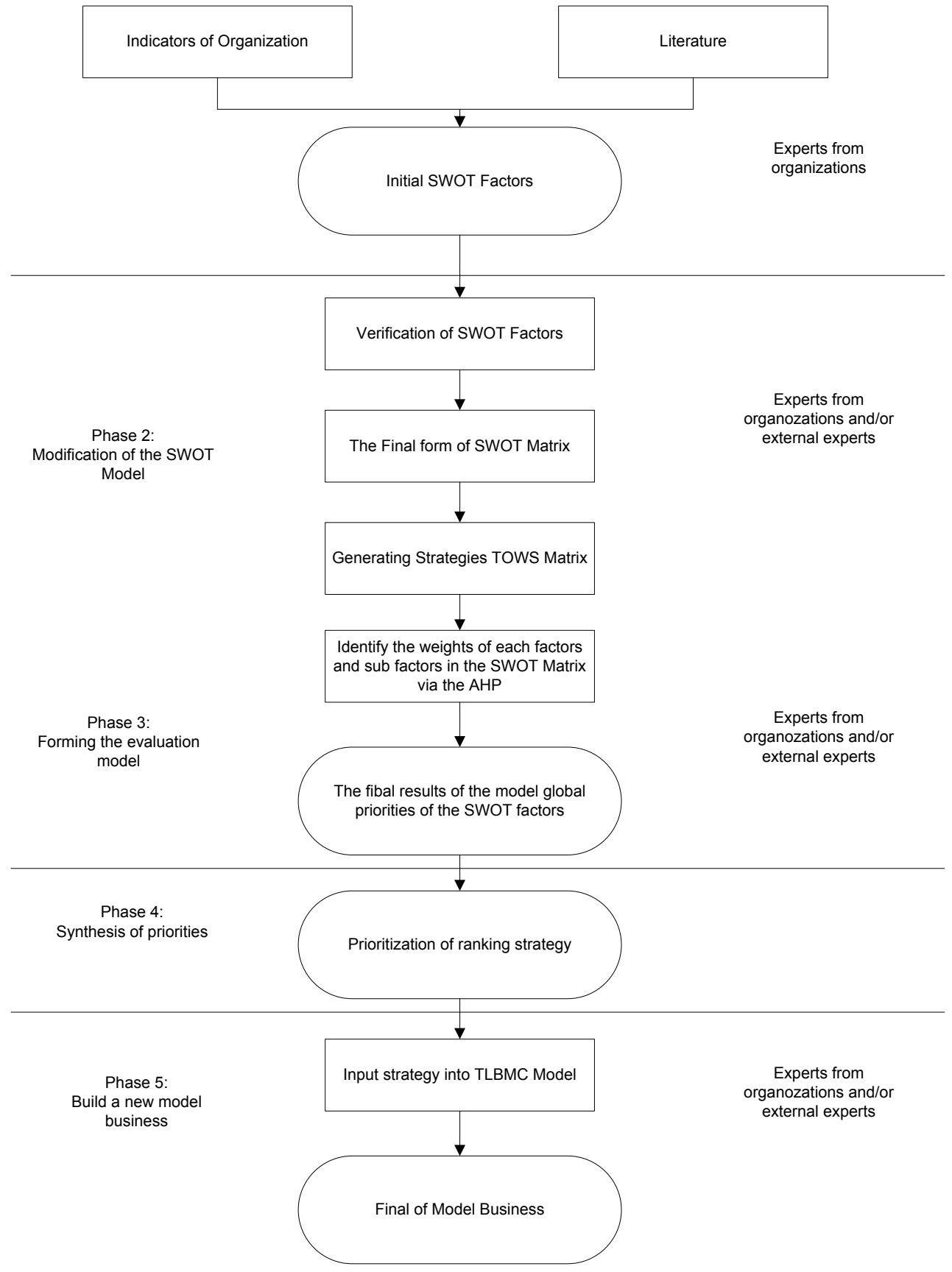

Fig. 1. Flowchart model.

Source: MS visio processing.

And the last step is to create a business model using TLBMC after in depth interview with experts on agrotourism business in Punten Village and also considering the relationship between strategy that has been formulated by using SWOT-AHP as an input and refinement on TLBMC business model. 


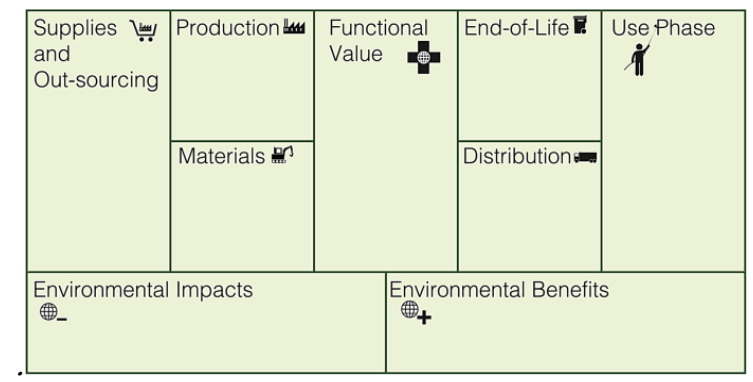

Fig. 2. Environment layer matrix columnof TLBMC.

Source : A. Joyce, R.L. Paquin / Journal of Cleaner Production 135 (2016) 1474-1486

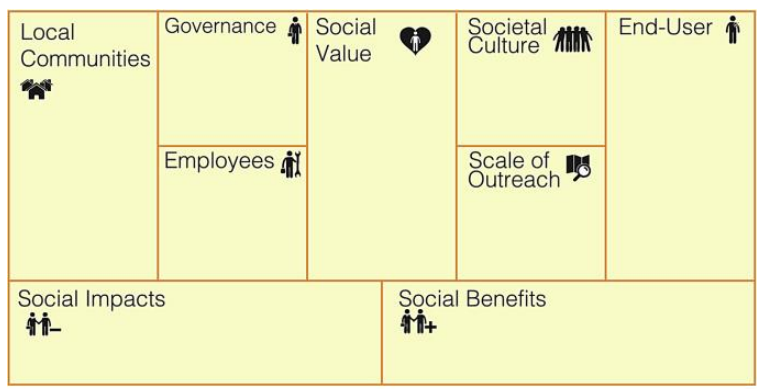

Fig. 3. Social layer matrix column of TLBMC.

Source : A. Joyce, R.L. Paquin / Journal of Cleaner Production 135 (2016) 1474-1486

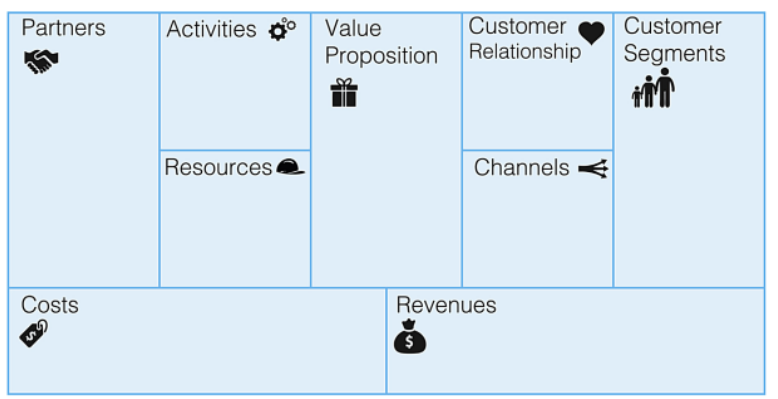

Fig. 4. Economic layer matrix column of TLBMC.

Sumber : A. Joyce, R.L. Paquin / Journal of Cleaner Production 135 (2016) 1474-1486

\section{Conclution}

In this study, it can be concluded that the new business model can be created by considering the environmental and social aspects in addition to the economic aspects that already exist in the previous business model canvas. And also the relationship between SWOT-AHP analysis with TLBMC so as to provide the best alternative solution to the condition of agro business in Punten Village will be selected several strategies: Progressive Strategy, Strategy Dissemination, Market Penetration and Product Development as a strategy that will build the agro business. And from the making the business model of TLBMC is expected to provide a sustainable business 
model. Future work in this research will be applied in case studies in manufacturing and service industries.

\section{References}

1. Blocher, E.J., C.H. Kung., Gary, dan T.W. Lin. Manajemen Biaya: Penekanan Strategis. Penerbit Salemba Empat. Jakarta. (2007)

2. Budiarti, S., Indonesian Journal of Agricultural sciences, 18 (2013)

3. Glaser, J.A., Policy, 8 (2006)

4. Hubbard, G., Strategy Environ, 18 (2009)

5. Law, R. R., Tourism Management, 27 (2011)

6. Lozano, R., J. Clean. Prod, 20 (2008)

7. Osterwalder, Alexander dan Pigneur, Yves. Business Model Generation. Jakarta: Elex Media Komputindo. (2012)

8. Wanti, S. Taufiqurrahman, dan D.D. Rahayu. Analisis Strategi Keunggulan Bersaing dengan Pendekatan Analisis SWOT pada Spartan Gym Pekanbaru. JOM Vekon. (2014) 